\title{
КНИГА АНАТОЛІЯ МІХНЬОВА «ОЧЕРКИ ПО ВОЕННО-ПОЛЕВОЙ ТЕРАПИИ» ТА СУЧАСНІСТЬ
}

\author{
М.П. Бойчак \\ Українська військово-медична академія (м. Київ)
}

Мета. Розглянути окремі глави книги Анатолія Міхньова «Очерки по военно-полевой терапии» $i$, по можливості, надати своє бачення актуальності деяких проблем, що піднімав автор «Очерков», з точки зору сьогодення

Матеріали та методи дослідження. В дослідженні використано історичний $і$ бібліосемантичний методи для повного розкриття актуальності деяких проблем, що піднімав А.Л. Міхньов в книзі «Очерки по военно-полевой терапии» з точки зору сьогодення.

Результати дослідження. Фундаментальні погляди А. Міхньова на етіопатогенез та терапію гострих бронхітів воєнного часу, деякі особливості перебігу крупозної пневмонії та їі лікування внутрішньовенним введенням сульфідину, патогенез та лікування легеневих нагнійних процесів, патогенез і терапію кардіопульмональної недостатності, аліментарну дистрофію, спільність симптомів та диференційну діагностику міокардіодистрофій, Брайтову хворобу $i$ аліментарну дистрофію, а також лікування малярії внутрішньовенним введенням хініну залишиаються актуальними і на теперішній час.

Висновки. Оскільки у надані медичної допомоги військовослужбовцям ЗС України на Сході України активну участь приймають терапевти і лікарі терапевтичного профілю (більшість санітарних втрат на цій війні $\epsilon$ втрати саме терапевтичного профілю), фундаментальні погляди А. Міхньова на етіопатогенез та терапію бойовоїтерапевтичної патології $\epsilon$ важливими $і$ не втрачають своєї актуальності. Звичайно $i$, це вже чітко встановлений факт - низка захворювань внутрішніх органів мають певні особливості перебігу, які залежать від багатьох факторів (від театру воєнних дій, їх інтенсивності, застосування сучасного озброєння $і$ бойової техніки, умов служби та побуту військовослужбовців тощо). Міхньов А.Л. звертає увагу на те, що умови служби і побуту бійців та командирів діючої армії у роки Другої світової війни «знижують загальну опірність організму $i$ послаблюють його сили в боротьбі з інфекцією. Ця обставина істотно позначається і на характері перебігу патологічного процесу, змінюючи клінічну картину цілого ряду захворювань, роблячи їі різноманітною, даючи нові якісні прояви при взаємодії хвороботворних агентів з макроорганизмом». Такі особливості є і тепер, а їх вивчення та вплив на здоров'я військовослужбовців, та на перебіг захворювань $\epsilon$ одним із завдань військово-медичної служби. Прикладом для такого вивчення і $\epsilon$ книга А.Л. Міхньова «Очерки по военно-полевой терапии».

Ключові слова: воєнно-польова терапія, етіопатогенез та терапія, кардіопульмональна недостатність, аліментарна дистрофія.

Вступ. Ми звикли, що старі книги 3 медицини цікаві лише з історичної точки зору, проте, листаючи давні медичні фоліанти ловиш себе на думці, що багато з них є актуальними і сьогодні. До таких книг відноситься і монографія видатного терапевта, кардіолога, доктора медичних наук, професора, заслуженого діяча науки А.Л. Міхньова «Очерки по военнополевой терапии, яка вийшла у 1946 році [1].

Минулого року українська лікарська спільнота відзначила 100-літній ювілей вченого, у цьому році виповнюється 50 років 3 дня його смерті. Крім відомих праць з внутрішніх хвороб, зокрема з кардіології, ревматології, гепатології, хотілось би відзначити внесок Анатолія Львовича Міхньова у розвиток і військової терапії.

Післявоєнне покоління вітчизняних терапевтів, військових лікарів виховані на підручниках та керівництвах з воєнно-польової терапії радянських та російських терапевтів професорів М.С. Молчанова (1961, 1973), Є.В. Гембицького та Ф.І. Комарова, А.Л. Ракова та А.Є. Сосюкіна, В.М. Клюжева. Проте, на жаль, ми мало знайомі 3 іншими книгами - працями українських вчених О.Я. Губергріца та А.Л. Міхньова, присвячених воєнно-польовій терапії, що вийшли у світ раніше, ніж вказані вище. Перші - написані військовими терапевтами, другі - цивільними терапевтами, доля яких кинула у вир Другої світової війни. Перші, за виключенням книг М.С. Молчанова, за змістом багато у чому повторюють одна одну, другі книги з оригінальним, індивідуальним змістом, від чого вони $є$ привабливими для читача, заставляють замислюватися над прочитаним, проводити паралелі із нинішніми уявленнями 
щодо патології внутрішніх органів, актуальної для військової медицини.

Книга А.Л.Міхньова стала другою у Радянському Союзі з питань воєнно-польової терапії після книги П.І.Єгорова «Вопросы военно-полевой терапии», що вийшла у 1945 році.

Учитель А.Л. Міхньова - академік М.Д. Стражеско, у передмові до «Очерков» писав: «Закончилась Отечественная война, благодаря ее размерам, продолжительности и особой жестокости, новым видам оружия и стратегическим приемам и новой военной тактике, больше всех предшествующих войн принесла новые заболевания, изменила подчас до неузнаваемости семиотику, течение и исход многих уже известных заболеваний.

Анализ всего накопленного за войну материала будет весьма полезен для понимания патогенеза, клиники и особенно для терапии. Опыт и наблюдения всех военных врачей должен быть зафиксирован и использован, что, несомненно, будет способствовать дальнейшему прогрессу клинической медицины.

Предлагаемые «Очерки по военнополевой терапии» доцента А.Л. Михнева, получившего хорошую клиническую подготовку еще до войны и лично наблюдавшего особенности течения различных заболеваний в военное время, и применившему на фронте современные методы лечения внутренних заболеваний, исходя из понимания их патогенеза, особенно интересны и поучительны. Они, несомненно, с одной стороны будут способствовать разъяснению некоторых сторон патогенеза затрагиваемых автором заболеваний, и с другой - принесут пользу врачам в их практической деятельности в мирное время».

Звичайно, що ми не ставили перед собою за мету детальний огляд захворювань, що викладені у книзі А.Л. Міхньова на сучасному рівні. Звернемо лише увагу на деякі актуальні для військової медицини питання у розрізі порушених автором проблем.

Мета. Розглянути окремі глави книги Анатолія Міхньова «Очерки по военно-полевой терапии» i, по можливості, надати своє бачення актуальності деяких проблем, що піднімав автор «Очерков», з точки зору сьогодення

Матеріали та методи дослідження. В дослідженні використано історичний і бібліосемантичний методи для повного розкриття актуальності деяких проблем, що піднімав А.Л. Міхньов в книзі «Очерки по военно-полевой терапии» 3 точки зору сьогодення.

\section{Результати дослідження.}

Етіопатогенез та терапія гострих бронхітів воєнного часу. Весною і восени 1942 року до терапевтичного госпіталю, де служив А.Л.Міхньов, поступила велика кількість хворих 3 клінічною картиною гострого бронхіту, яка значно відрізнялася від клінічної картини гострих бронхітів мирного часу.

Це були хворі з більш важким перебігом захворювання, що характеризувалася значною задишкою, яка посилювалася при незначних фізичних загрузках та уночі; нестерпним кашлем 3 невеликою кількістю мокроти, яка важко відходила, відчуттям стискання у грудях.

При об'єктивному обстеженні виявлялися виражені зміни, які нагадували клінічну картину бронхіальної астми або хронічного бронхіту, що затрудняло діагностику i призводило до помилок. Зокрема, часто відмічались ціаноз шкіри обличчя та видимих слизових оболонок, експіраторна задишка. Температура тіла була нормальною, або субфебрильною, рідко досягала 38 град. Перкуторний звук над легенями був ясним або 3 коробочним відтінком. Дихання жорстке 3 великою кількістю сухих свистячих та дзижчатих хрипів. Зі сторони серцево-судинної системи звертала на себе брадикардія, гіпотонія.

В етіології гострих бронхітів основна роль належала різним інфекційним чинникам (вірусам грипу, пневмококам, мікрококам, диплококам, стрептококам, бацилам Пфейфера тощо).

Факторами, що сприяли захворюванню були усі ті моменти, що визивали ослаблення організму, в першу чергу - переохолодження. У патогенезі розвитку гострих бронхітів А.Л. Міхньов придавав важливе значення розладу функції вегетативної нервової системи, а саме підвищенню тонусу блукаючого нерва. Катаральний ексудат, що утворювався та скупчувався у бронхіальному дереві у вигляді мокроти визивав подразнення легеневих гілок блукаючого нерва, що у свою чергу призводило до його збудження i, відповідно, до бронхоспазму.

Захворювання протікало довго, погано піддавалося загальноприйнятому лікуванню симптоматичними засобами. Інколи хворих виписували з госпіталю ще не зовсім здоровими. Це приходилося робити, адже вони «вибирали» усі встановлені терміни лікування гострого бронхіту. Інколи гострий бронхіт із-за важкості перебігу приймався за більш важке 
захворювання і тоді таким хворим виносився невірний експертний висновок i вони признавалися не придатними до військової служби.

Знання патогенезу дозволило запропонувати ефективні підходи до лікування. Враховуючи те, що в основі патогенезу важливу роль відігравав підвищений тонус блукаючого нерва 3 тенденцію до бронхоспазму, то було запропоновано лікування таких хворих атропіном (підшкірно 0,1\% розчин по 1,0 мл. на протязі 12-14 днів) , який усував вплив блукаючого нерва на гладку м'язову оболонку бронхів, а також призводив до зменшення секреції в'язкого ексудату слизовою бронхів.

Після призначення атропіну, поряд 3 іншим, симптоматичним лікуванням, на протязі 12-14 днів у 52 хворих із 63 наступило повне одужання. Швидко проходили задишка, болісний кашель, відчуття стиснення у грудях, нормалізувався пульс, щезали патологічні симптоми бронхоспазму при об'єктивному обстеженні легенів. В 11 випадках залишались залишкові явища захворювання, що розцінювалось як загострення хронічного бронхіту. Застосування у цієї категорії хворих атропінізації в комбінації з серцевими засобами досить часто теж давало позитивний ефект.

Лікування гострих бронхітів проводилося у медико-санітарних батальйонах та у польових пересувних госпіталях. До фронтових госпіталів та евакогоспіталів такі хворі не направлялися.

\section{Актуальність проблеми для}

сьогодення. Розглядаючи актуальність гострих бронхітів для української армії у контексті праці А.Л. Міхньова на сьогодні, вважаємо за необхідне виділити два питання:

1. Розповсюдженість захворювань органів дихання серед військовослужбовців 3С України, зокрема гострих бронхітів. Чи мають вони таке ж значення як і у роки Другої світової війни?

2. Чи залишаються питання лікування гострих бронхітів такими же актуальними як і для А.Л. Міхньова у роки війни?

Відповідаючи на перше питання, слід зазначити, що захворювання органів дихання у військовослужбовців $3 \mathrm{C}$ України займають провідне місце і мають тенденцію до зростання. Аналіз динаміки первинної захворюваності серед військовослужбовців строкової служби за основними класами свідчить, що зростання відбувається в основному за рахунок хвороб органів дихання (46\%). У структурі первинної захворюваності офіцерів і військовослужбовців за контрактом - відповідно 46,1\% та 45,8\%. У структурі госпіталізованої захворюваності хвороби органів дихання теж посідають перше рангове місце серед усіх категорій військовослужбовців [2].

Цікаво, що при багаторічному аналізі (з 2004 до 2013 р.) спостерігалося зростання первинної захворюваності усіх категорій військовослужбовців на хвороби органів дихання у 2 рази, а у військовослужбовців строкової служби - у 3,4 рази [3].

Серед хвороб органів дихання саме гострі бронхіти $\epsilon$ самим розповсюдженим захворюванням i призводять до значних трудовитрат. У структурі хвороб органів дихання вони становлять більше ніж 50\%. Враховуючи те, що не всі автори виділяють гострий бронхіт в окрему нозологічну форму, а відносять його до категорії гострих респіраторних захворювань, де він i «розчиняється», то доля його серед інших хвороб органів дихання буде ще більшою.

Не меншою проблемою $є$ гострі бронхіти i у військовослужбовців, які приймають участь у бойових діях на Сході України. За медичною допомогою до лікарсько-сестринських бригад (перша лікарська допомога) 3 приводу захворювань органів дихання виявлено наступне. У зоні АТО першого ешелону 3 явищами бронхіту звернулося 69\%, у другому ешелоні - 90\%. На всі інші випадки респіраторної інфекції (риніти, фарингіти, тонзиліти, пневмонії тощо) прийшлося тільки 31\% і 10\% хворих відповідно. Таким чином, хворі на гострі бронхіти військовослужбовці, як в умовах мирного часу, так і під час бойових дій складають левову частку серед інших захворювань органів дихання, що безумовно впливає на боєздатність особового складу. Ефективність лікування гострих бронхітів набуває особливого значення, адже мова йде про скоріше повернення бійців до лав [4].

Що стосується другого питання, а саме лікування гострих бронхітів, то тут теж не так все просто. Досвідчені терапевти знають, як буває не просто справитися з лікуванням цього, здавалось б, легкого захворювання.

Так, не завжди легко вирішити: чи призначати антибіотики хворому, або обійтися симптоматичним лікуванням? Адже не завжди просто встановити, що на даний момент превалює в етіології захворювання - вірус, чи бактеріальна флора. Необхідно пам'ятати, що бактеріальна етіологія гострого бронхіту має місце лише у 10\% випадків [5]. Якщо призначати антибіотик - то коли і який? 
Не зупиняючись детально на цьому питанні, адже йому присвячена значна література, зробимо лише узагальнюючий висновок. Останні дослідження свідчать про те, що антибактеріальну терапію при гострих бронхітах необхідно призначати лише при наявності бактеріальних збудників захворювання, при важкому його перебігу , при підозрі на пневмонію, в осіб похилого віку, при важких супутніх захворюваннях та особам 3 любими формами імунодефіциту. Зауважимо, що у роки Другої світової війни у Червоній армії антибіотики не застосовувалися.

Інша проблема, яка $\epsilon$ актуальною i сьогодні, це лікування кашлю. Сухий, чи малопродуктивний кашель, який буквально «вивертає» хворого навиворіт, від кашлю болить вся грудна клітка і живіт, нічний кашель не дає виспатися. Випробовуються різні засоби проти кашлю, але останній не проходить і може турбувати хворого декілька тижнів. Хворий 3 розпачем приходить до лікаря, просить допомоги. Не дивлячись, що сьогодні арсенал мукоактивних засобів досить великий, не завжди легко вирішити, здавалося би, це просте питання.

Звичайно, що сучасний арсенал для лікування гострих бронхітів далеко не той, що був у роки Другої світової війни, можливості терапії набагато більші. У зв'язку з цим хотілося би звернути увагу на рекомендації А.Л. Міхньова щодо усунення явищ бронхоспазму у хворих на гострий бронхіт. Сьогодні про такий важливий елемент патогенезу гострого бронхіту як бронхоспазм нерідко забувають і бронхолітичні препарати не завжди призначаються.

Варто зазначити, що відомий пульмонолог О.Г.Чучалін у патогенезі захворювання придає важливе значення саме розвитку бронхоспазму. При активному запальному процесі підвищується чутливість рефлексогенних зон слизової оболонки бронхів, що визиває надсадний, болісний кашель, який провокується різними подразниками: низкою температурою повітря, зміною температури повітря тощо. При гострому бронхіті можливий розвиток бронхообструктивного синдрому [6]. Навіть у потенційно здорових людей вірусна інфекція здатна формувати тимчасову гіперреактивність бронхів і підвищує ризик розвитку бронхіальної астми [7].

У роки війни, у розпорядженні терапевтів був невеликий перелік засобів для ліквідації бронхоспазму. Сьогодні - цей потенціал значно більший. Ми маємо три групи препаратів щоби регулювати просвіт бронхів: симпатоміметики (селективні бета-2-агоністи) - сальбутамол, тербуталін та інші; холінолітики - іпратропіум бромід (атровент) та тіотропія бромід (спирива); метилксантини - теофілін, еуфілін та інші.

Ми не маємо на меті зупинятися на всіх засобах лікування кашлю, але згадуючи рекомендації А.Л. Міхньова щодо застосування холінолітика атропіна 3 хорошим ефектом, хотіли би привернути увагу до його слушної пропозиції використання цієї групи препаратів у лікуванні гострого і хронічного бронхіту. Тоді був атропін, а сьогодні холінолітики нового покоління - атровент, спіріва. Фармацевтичні компанії працюють, у тому числі, над пошуком нових холінолітиків для лікування захворювання легенів, адже вбачають у цьому напрямку перспективу. Ця група препаратів сприяє не тільки прямій бронхолітичній дії на середні та великі бронхи за рахунок зниження їх тонусу, але i за рахунок зменшення секреції слизової бронхів.

Порівняємо ці сучасні уявлення про механізм дії антихолінергічних препаратів 3 уявленнями А.Л.Міхньова: «Исходя из того, что, по нашому мнению, в основе патогенеза острого бронхита военного времени лежит повышение тонуса блуждающего нерва, мы предложили с лечебной целью проводить такого рода больным систематическую атропинизацию, имея в виду тем самым устранить влияние блуждающего нерва на гладкую мускулатуру бронхиального дерева, а также уменьшить секрецию вязкого экссудата слизистыми бронхов».

Про деякі особливості перебігу крупозної пневмонії та їі лікування внутрішньовенним введенням сульфідину. Відносно особливостей перебігу крупозної пневмонії, то А.Л.Міхньов зупинився тільки на двох ï проявах: реакції білої крові та температурній реакції. Питання клініки, етіології та патогенезу не аналізував, так як «це питання сьогодні добре вивчено i чудово викладено у цілому ряді керівництв 3 внутрішньої патології».

У класичному варіанті для крупозної пневмонії характерним був значний лейкоцитоз - до 25-40 тис. і навіть більше, нейтрофільоз, еозинопенія. В обстежених А.Л. Міхньовим 257 хворих спостерігалася зовсім інша картина. У більшості хворих (67\%) мала місце лейкопенія або нормальна кількість лейкоцитів, незначний лейкоцитоз був у 22\%, виражений лейкоцитоз у 11\% випадків. Абсолютна і відносна лімфопенія мала місце у 43\%. Щоби впевнитися 
у дійсності цих показників дослідження крові проводилося повторно на 2-й, 3-й, 4-й день захворювання. Дослідження проводилося до призначення сульфідину, тому виключався медикаментозний вплив на картину крові.

Нормальна картина крові у хворих, особливо коли були відсутні стетоакустичні симптоми пневмонії, нерідко дезорієнтувало лікаря у можливості правильної діагностики. Тому у таких випадках вирішальне значення мало рентгенологічне дослідження. Вказані зміни крові автор пояснював зниженням реактивності організму за рахунок, в основному, виснаження фізіологічної системи сполучної тканини.

По цій же причині у хворих на лобарну (крупозну) пневмонію спостерігалася нормальна або незначно підвищена температура тіла, особливо в осіб з кахектичною формою аліментарної дистрофії. Остання, на думку А.Л. Міхньова, була причиною не тільки вказаних змін зі сторони гемопоетичної системи та терморегуляції, але і атипового перебігу багатьох захворювань.

Лікування сульфідином - одним з перших сульфаніламідних препаратів, у 1942-1944 рр. було відносно новим методом лікування. Нагадаємо, що сульфідин був створений одеситом Ісааком Яковичем Постовським у 1937 р., у роки Другої світової війни організовано його промислове виробництво (1942), вивчена фармакодинаміка і фармакокінетика препарату. 31942 р. Препарат став застосовуватися у клінічній практиці. При застосуванні сульфідину всередину нерідко розвивалися побічні дії (в основному зі сторони шлунково-кишкового тракту) і для досягнення клінічного ефекту необхідно було застосовувати великі дози препарату. У важких хворих повноцінно застосовувати препарат перорально було тим більше не можливо - розвивалася «сульфідинова криза» 3 посиленням інтоксикації і порушеннями зі сторони серцевосудинної і дихальної систем. Внутрішньовенне застосування сульфідину дозволило суттєво зменшити дози препарату при збереженні терапевтичного ефекту і суттєвого зменшення його побічної дії. Результати лікування виявилися вражаючими - летальність знизилася у багато разів - 3 30\% до 4-6\% [8].

А.Л. Міхньов був одним 3 перших радянських авторів, хто став застосовувати сульфидин внутрішньовенно. Нагадаємо, що свої спостереження він проводив саме у 1942 р., коли препарат тільки появився для клінічного застосування. Пропонувалися різні схеми його внутрішньовенного введення. Схема, яку запропонував Анатолій Львович, виявилася значно ефективнішою, ніж в інших авторів. 3 257 хворих, що лікувалися за його методикою, помер тільки один хворий, що поступив на 11 день захворювання $з$ тотальною двобічною пневмонією, у коматозному стані 3 менінгіальним симптомокомплексом. 256 випадків захворювання закінчилися повним одужанням, без будь-яких ускладнень, що для тих років було досить вражаючим досягненням.

Цей матеріал А.Л.Міхньов у 1945 р. Доповів на засіданні наукового терапетичного товариства Києва, надрукував у журналі «Врачебное дело» [9].

Актуальність проблеми для съогодення. Після активного i широкого застосування у 50-70 роках антибіотиків (пеніцилін та інші) для лікування пневмонії, смертність від цього, раніше загрозливого захворювання, ще більше зменшилася. Казалося би, що проблема вирішена. Проте в останні десятиріччя питання актуальності лікування пневмонії знову стало очевидним та актуальним. Якщо у 1901 р. У.Ослер назвав пневмонію «водієм ешелону смерті», то після винайдення антибіотиків вона перестала бути цим «водієм», проте не надовго. У кінці 20 ст. вона знову заявила про себе, ставши однією з причин смерті людей. На сьогодні пневмонія $\epsilon$ третьою ранговою причиною смертності населення в світі.

Захворюванність на негоспітальні пневмонії (НП) серед військовослужбовців, особливо строкової служби, не дивлячись на усі зусилля медичної служби, теж залишається високою. Перебіг захворювання характеризується важкістю та ускладненнями, трапляються летальні випадки.

Як і раніше зостається проблема пізньої діагностики НП, повязанною із невчасним зверненням віськовослужбовців за медичною допомогою та помилками у діагностиці на догоспітальному етапі (не виявлене захворювання).

Смерть військовослужбовця від НП завжди резонансна подія не тільки в армії, але і в суспільстві в цілому, стає приводом до розслідування причини смерті як в армійському середовищі, так і громадськістю (журналістами, союзами солдатських матерів тощо), викриває недоліки i, навіть, злочинну халатність командирів різного рангу по відношенню до солдатського життя.

При лікуванні НП 3 використанням антибіотиків, на жаль, лікарями допускається 
теж багато помилок. Не завжди правильно вибирається шлях введення антибіотика, группа препарата, його доза та тривалість лікування, пізній початок лікування, часта зміна антибактеріального препарату. Не всі лікарі знають що таке ступенева антибактеріальна терапія чи деескалаційна терапія [10]. Проблема із раціональним застосуванням антибактеріальних препаратів має місце і в середовищі військових лікарів. Проведене анонімне анкетування серед слухачів Української військово-медичної академії виявило недостатній рівень обізнаності слухачів-лікарів щодо питань, пов'язаних із показаннями до застосування, ефектами антибактеріальних препаратів та принципами раціональної антибіотикотерапії [11].

На прикладі цієї глави можна впевнитись, що загальні підходи до діагностики та лікування пневмоній, зокрема і у військовослужбовців, залишились незмінними. Важливо визначити особливості перебігу захворювання у воєнний час, встановити ступінь важкості пневмонії, виявити ті, чи інші зміни зі сторони крові i, враховуючи всі ці зміни, підібрати відповідну терапію. А.Л. Міхньов, маючи солідну клінічну і теоретичну підготовку, отриману до війни в Інституті клінічної медицини під керівництвом М.Д. Стражеска, зумів встановити причини тих чи інших змін у перебігу пневмоній воєнного часу (виснаження фізіологічної системи сполучної тканини, аліментарна дистрофія). Цікаві його роздуми над механізмом дії сульфидина, які певною мірою узгоджуються із сучасними поглядами на механізм дії антибактеріальних препаратів (перешкоджають інкапсуляції мікробів, «нейтрализуют какую-то фазу обмена или ферментативную деятельность бактерий», нейтралізують бактеріальні ендотоксини, підвищують активність фізіологічної системи сполучної тканини).

Будучи одним 3 перших розробників внутрішньовенного лікування важких пневмоній сульфаніламідами (сульфідин) А.Л. Міхньов показав зразок підходу до вивчення фармакодинаміки препарату та методики його застосування (значення шляхів введення препарату, як уникнути побічних дій, визначення ефективної дози та кратності введення препарату, тривалості лікування, загальної його кількості на курс лікування). Врахування цих факторів дозволили автору методики отримати блискучі результати лікування, які на його думку пов'язані не тільки із самим препаратом, але i вибором внутрішньовенного шляху введення, який дозволив швидко і у достатній концентрації накопичитись препарату у малому крузі кровообігу, i що особливо важливо - на початкових стадіях захворювання. Всі ці особливості застосування антимікробної хіміотерапії зберігаються і в наші дні.

Патогенез та лікування легеневих нагнійних процесів. На початку цієї глави А.Л. Міхньов детально наводить огляд літератури (вітчизняної та іноземної) щодо частоти, причин розвитку та лікування нагнійних захворювань легень.

Якщо до війни нагнійні процеси в легенях рахувалися рідкісними захворюваннями, то у роки війни вони зустрічалися набагато частіше. Це було пов'язано як 3 покращенням їx діагностики (практично у кожному евакогоспіталі був рентгенівський апарат), а також зі збільшенням частоти пневмоній. Пневмонії ускладнювалися розвитком абсцесів, за даними різних авторів, від 3\% до 44\%.

А.Л. Міхньов спостерігав 103 хворих на метапневмонічні легеневі нагнійні процеси (абсцеси та гангрени).

Вивчення їх етіології та патогенезу дозволило йому сформулювати уявлення відносно розвитку цих патологічних процесів.

Етіологічним чинником була як аеробна та анаеробна інфекція, яка з вогнища запалення розповсюджувалася, в основному бронхогенним шляхом. Велике значення надавалося запальним процесам у самих бронхах, що призводило до порушення їх функції, сприяло їх обтурації слизом та іншими продуктами запалення. Як наслідок - розвиток інфікованих ділянок ателектазу, які потім давали початок легеневому абсцесу.

Гангрена та абсцес легенів являлися різними стадіями єдиного запального процесу пневмонія - абсцес - гангрена.

Крім прямого токсичного впливу інфекції на патологічно змінену легеневу тканину велике значення мав стан фізіологічної системи сполучної тканини, від якої залежав стан клітинного та гуморального імунітету.

Виходячи 3 цих уявлень щодо етіології і патогенезу захворювань будувалося і лікування легеневих нагноєнь. Це застосування антибактеріальних засобів (неосальварсан, уротропін, риванол тощо) та антиретикулярної цитотоксичної сироватки (АЦС) Богомольця. Хірургічне лікування застосовувалося рідко, так як післяопераційна летальність була високою навіть у руках досвідчених хірургів, тому не оправдовувало себе. Техніка легеневої хірургії у 
ті часи була ще не відпрацьована на належному рівні.

А.Л. Міхньов поділився результатами лікування 103 хворих на післяпневмонічні нагнійні процеси (98 хворих на абсцес і 5 - на гангрену легень). Більшість хворих знаходилася у важкому стані з явищами виснаження. На попередніх етапах лікування хворі вже отримували загальноприйняте лікування без належного ефекту.

Усім хворим призначалася АЦС по 0,05-0,1 на ін'єкцію через два дні на третій, на курс від 3 до 5 ін'єкцій. Крім АЦС одночасно проводилося внутрішньовенне вливання $1 \%$ ріванолу.

Шляхом співставлення 3 іншими методами лікування виявилося, що комбінована терапія легеневих нагноєнь АЦС у поєднанні 3 риванолом давало найкращий ефект. Із 103 хворих, що лікувалися таким методом, прослідковано до кінця 76, інші 27 хворих, за умовами бойової обстановки були евакуйовані у тилові евакогоспіталі.

Із 76 випадків, що прослідкував автор, у 53 (70\%) наступило клінічне одужання, у 10 (13\%) - покращення, не було ефекту у 8 хворих (10,5\%), померло 5 (6,5\%). Такий результат для років Другої світової війни можна рахувати навіть блискучим. За даними літератури, які наводить А.Л. Міхньов, результати консервативної терапії легеневих нагнійних захворювань були суперечливими. Одні автори наводили $20 \%$ одужань, інші $50 \%$, а за спостереженнями М.Д. Стражеско одужувало $78 \%$ хворих. Суперечливими були і дані по смертності, яка досягала від 30\% до $80 \%$. На фоні цих показників результати лікування, отримані А.Л. Міхньовим у роки війни були вражаючими.

\section{Актуальність проблеми для} сьогодення. Не дивлячись на досягнення антибактеріальної терапії за даними чисельних авторів, повне одужання спостерігається у 25$40 \%$, клінічне - у 35-40\%, перехід у хронічну форму - у 15-20\% хворих, летальність становить 5-10\% [12, 13]. Якщо врахувати, що більшість хворих 3 абсцесами легенів (до 90\%) виліковуються одним тільки консервативним лікуванням, то актуальність для терапевтів цієї патології $\epsilon$ надзвичайно важливою. При цьому необхідно розуміти, що консервативне лікування це не тільки дача антибіотиків та інших медикаментів, це активні втручання із застосуванням лікувальної бронхоскопії, трансторакального мікродренування абсцесу легені, мікротрахеостомії, екстракорпоральні методи детоксикації та інші, які мають проводитись у спеціалізованих пуль монологічних відділеннях. Слід зазначити, що деякі 3 цих методів використовувались ще у роки Другої світової війни, про які згадував і А.Л. Міхньов (аспірація вмісту абсцесу бронхоскопом, накладення пневмотораксу, френікоексерез). Сучасний фахівець має володіти цими інструментальними мініінвазивними методами лікування.

Патогенез i терапія кардіопульмональної недостатності. На початку цієї глави А.Л. Міхньов дає короткий історичний екскурс, присвячений історії розвитку вчення про сутність недостатності кровообігу, що була сформована у клініці М.Д. Стражеско. Використовуючи сучасні для того часу методи дослідження гемодинамічних та обмінних процесів в організмі, М.Д. Стражеско зі своїми учнями підійшов не тільки до розуміння патології кровообігу, але вивчивши їі, зрозумівши причини та патогенез недостатності кровообігу, використав отримані дані в інтересах лікування та запропонував разом 3 В.Х.Василенко власну класифікацію недостатності кровообігу, що була прийнята 12м Всесоюзним 3'їздом терапевтів.

А.Л. Міхньов у даній главі розглянув питання розвитку недостатності кровообігу при патології органів дихання, чим суттєво доповнив уявлення про серцеву недостатність у цієї категорії хворих. Симптомокомплекс сецевої недостатності пов'язаної із захворюваннями апарату зовнішнього дихання отримав визначення, як кардіопульмональна недостатність. Раніше, старими авторами, цей симптомокомплекс називався кардіопульмональним синдромом.

Хвороби системи зовнішнього дихання, що об'єднували емфізему легень, хронічний бронхіт, пневмосклероз, пневмоконіоз, бронхоектази, як проблема клінічної патології в умовах війни, набували досить актуального значення, з однієї сторони - у сенсі визначення придатності таких хворих до військової служби, з другої - з'ясування причин, що сприяли у них швидкому розвитку декомпенсації кровообігу.

У практичному відношенні автора більше всього цікавила емфізема легень. Розглядаючи проблему емфіземи легень з позиції нозології і патогенезу, А.Л. Міхньов наголошував, що як ізольований симптомокомплекс емфізема не зустрічається. Сформульоване, більше ніж 100 років назад, Р.Лаеннеком положення, що «не існує емфіземи без хронічного бронхіту», не втратило свого значення і в роки Другої світової війни. 
3 точки зору патогенезу емфізема легень хронічний бронхіт $\epsilon$ процесами, що розвиваються паралельно, адже в їх основі лежать одні i ті ж запальні процеси, що визивають атрофію активних елементів тканин бронхів і легень. Основна роль у розвитку емфіземи належала конституціональним особливостям мезенхімальних елементів і проявлялася у складній морфологічній їх реакції. Менше значення у розвитку емфіземи надавалося автором механічному фактору, що визивався тривалою затримкою повітря у легенях під великим тиском.

Мало що змінилося у трактуванні емфіземи легень і сутності кардіопульмональної недостатності як iㅣ бачив А.Л.Міхньов від нинішніх уявлень щодо цієї патології. Можливо лише добавити, що сьогодні виділяється ще первинна емфізема, пов'язана з дефіцитом $\alpha 1$ антитрипсину.

3 липня 1942 p. до квітня 1944 p. А.Л.Міхньов спостерігав 2176 хворих 3 кардіопульмональної недостатністю. 3 них, 3 недостатністю кровообігу 1-ї ст. було 215 чоловік, 2-ї А ст. - 1008, 2-ї В ст. - 88, 3-ї ст. - 73. Крім клінічного обстеження усім хворим проводилося вимірювання швидкості кровообігу, венозного та артеріального тиску, життєвої ємкості легень. Усі обстеженні були, в основному, у 40-50- річному віці. До призову в армію більшість хворих виконували фізичну працю на підприємствах або сільському господарстві, не відзначаючи серйозних розладів функції дихання та серцево-судинної системи, за виключення задишки, що наступала після стомлення.

У чому автор бачив сутність патогенезу кардіопульмональної недостатності? Апарат кровообігу i апарат зовнішнього дихання розглядалися як дві частини однієї системи дихання тканин, причому апарат зовнішнього дихання $\epsilon$ не тільки частиною цієї системи, але в той же час і додатковий «двигун» кровообігу, один 3 двох «двигунів», що здійснюють у значній мірі зворотній приток крові до серця.

Дихальні екскурсії $\epsilon$ активними гемодинамічними факторами: під час вдиху вони збільшують наповнення легень кров'ю, при кожному видиху - зменшують. Завдячуючи еластичності легень та їх постійному намаганні скоротитися, тиск у грудній порожнині нижчий, ніж у зовнішній атмосфері; у кінці вдиху негативний тиск досягає свого максимуму; таким чином, при кожному вдиху збільшується наповнення венозної частини серця. Тож очевидно, що різноманітні захворювання легень, що супроводжуються значним зменшенням дихальної поверхні, редукцією капілярної сітки малого кола кровообігу i порушенням еластичної тяги легень, значно відображаються на гемодинаміці і визивають посилену роботу правого серця.

Зменшення кількості легеневих капілярів призводить до збільшення опору току крові у легенях; внаслідок цього наступає гіпертрофія правого шлуночка, так як компенсація недостатньої функції апарату дихання i утрудненої роботи апарату кровообігу можливі тільки при збільшенні роботи правого серця. При таких максимальних навантаженнях серця його компенсаторні можливості вичерпуються і наступає його міогенна дилатація, що свідчить про слабкість міокарда.

Не зупиняючись на клінічній картині серцево-легеневої недостатності в обстежуваних хворих, яку приводить А.Л.Міхньов, привертаємо увагу лікарів на можливість виникнення у таких хворих раптової смерті, описаної автором у цих хворих: «раптової тихої смерті, що наступає вночі у вісні, а також коли людина сидить де-небудь за столом, коли серце зразу зупиняється без попередніх больових нападів, без задухи». Виникнення раптової смерті автор пояснював глибокими біохімічними змінами серцевого м'язу.

Ще одним незвичайним клінічним проявом кардіопульмональної недостатності, що спостерігався автором, був грізний стан гострої слабості правого серця, який проявлявся нападом своєрідної форми серцевої астми 3 різко вираженим ціанозом шкіри, але без аускультативних проявів застою у легенях.

А.Л. Міхньов звертав увагу також на випадки, коли при емфіземі не було клінічних проявів серцевої недостатності, проте при морфологічному дослідженні у померлих виявлялася гіпертрофія правого серця і жирове переродження м'язових волокон.

Основними причинами, що сприяли розвитку декомпенсації кровообігу в обстежених хворих були: загострення хронічного бронхіту, що виникали у зв'язку 3 частими переохолодженнями, перебуванням у сирій місцевості, значні фізичні перенавантаження. Усі ці фактори призводили до прогресування емфіземи та створювали несприятливі умови для діяльності правого серця.

Лікування хворих $з$ легенево-серцевою недостатністю проводилося за тими же принципами, як і лікування серцевої 
недостатності взагалі. У випадках гострої слабості правого серця, що проявлялася у приступі своєрідної форми серцевої астми, проводилося негайне кровопускання 500-600 гр. крові, з послідуючим введенням 50-100 гр. 40\% розчину глюкози, меркузал і строфантин, що давало можливість спасати таких хворих.

\section{Актуальність проблеми}

для

сьогодення. Актуальність піднятої А.Л. Міхньовим проблеми кардіопульмональної недостатності у роки війни вбачаємо у наступному:

1. Не дивлячись на значні досягнення у лікуванні хронічного обструктивного захворювання легень (ХОЗЛ), власне до якого увійшли захворювання, які досліджувалися автором (хронічний бронхіт, емфізема легень, пневмосклероз), хронічна серцева недостатність $(\mathrm{XCH})$, що його ускладнює, зустрічається не менш часто ніж у роки війни і $\epsilon$ однією 3 проблем як пульмонології так кардіології: «Поєднання ХСН та ХОЗЛ породжує низку клінічних проблем, поки далеких від успішного вирішення» - професор Л.Г. Воронков (керівник відділу серцевої недостатності Інституту кардіології імені М.Д.Стражеска). За даними сучасних дослідників поширеність ХСН у хворих на ХОЗЛ коливається від 10 до 46\%, при чому поширеність недіагностованої ХСН у пацієнтів 3 ХОЗЛ старших за 65 років складає 20\%. Ризик розвитку серцевої недостатності (CH) у пацієнтів з ХОЗЛ у 4,5 рази вищий, ніж у контрольній групі відповідного віку [14]. Основною причиною смерті від ХОЗЛ є хронічна легенево-серцева недостатність [15]. Нині термін «легенево-серцева недостатність» зустрічається рідко, легенева патологія розглядається як одна 3 причин ХСН (CH). Використовується також термін «хронічне легеневе серце». За виначенням робочої групи фтизіатрів і пульмонологів України: хронічне легеневе серце - це синдром недостатності кровообігу з розвитком периферичних набряків, що ускладнює перебіг багатьох захворювань (за винятком серця), що вражають структуру або тільки функцію легенів» [16]. Багато дослідників відмічають, що нерідко СН не діагностується у хворих на ХОЗЛ, за цього вони не отримують кардіотропну терапію i помирають від серцево-судинних проблем, а не від прогресування власне респіраторного захворювання. Про важливість ураження серця при емфіземі легень ще у роки війни писав А.Л. Міхньов: «При клиническом исследовании больных с эмфиземой легких и учете их трудоспособности мы, прежде всего, пытались определить степень функциональной недостаточности сердечно-сосудистой системы, пользуясь классификацией недостаточности кровообращения акад. Н.Д.Стражеско и проф. В.Х.Василенко. Этот вопрос является сугубо принципиалтным, особенно с точки зрения военно-врачебной экспертизы». Проблема сьогодення заключається і в тому, що ХОЗЛ часто поєднується з ішемічною хворобою серця (IXC), артеріальною гіпертензією (АГ), що викликає труднощі у діагностиці та лікуванні кожного з цих захворювань [17].

2. До початку 2000-х років симптоми ХСН у хворих на ХОЗЛ традиційно вважались ознакою недостатності правих відділів серця (cor pulmonale), тобто це були уявлення воєнних i післявоєнних років, коли обстежувалися пацієнти переважно молодого і середнього віку із тяжкими хронічними захворюваннями легень, без супутньої IXC. Всі ці роки панувало уявлення, що у цих хворих 3 ознаками ХCH лівошлуночкова дисфункція не відіграє суттєвої ролі. I тільки на початку нинішнього століття було встановлено, що в кожного п'ятого хворого 3 ХОЗЛ виявляється недіагностована лівошлуночкова $\mathrm{CH}$. $\mathrm{y}$ послідуючих дослідженнях було встановлено, що у хворих на ХОЗЛ часто спостерігається не виявлена гіпертрофія лівого шлуночка (ЛШ), а також його систолічна і діастолічна дисфункція. Більше того, з часом вчені прийшли до висновку, що порушення структури та функції ЛШ $€$ ключовими чинниками розвитку симптомів ХСН у переважної більшості хворих на ХОЗЛ. Ці порушення посилюються супутніми серцевосудинними захворюваннями (IXC, АГ), які $\epsilon$ найпоширенішою коморбідністю ХОЗЛ (до 70\% хворих). Проте показані також прямі механізми впливу Х0ЗЛ на міокард, у тому числі ЛШ, при відсутності супутніх серцево-судинних захворюваннях. Відзначене вище, звичайно, не виключає ролі структурно-функціональних змін правого шлуночка (ПШ) як у розвитку правошлуночкової недостатності, так i погіршення функції Лш через механізми інтравентрикулярної взаємодії (підвищення тиску в ПШ і збільшення його об'єму приводять до руху міжшлуночкової перетинки в сторону ЛШ зі зміною його геометрї̈ («D-shape»). Дилатація ПШ збільшує також конструктивний ефект перикарда. Ці механізми призводять до зменшення розтягнення i наповнення ЛШ i пояснюють чому спостерігається збережена фракція ЛШ не дивлячись на субоптимальне його наповнення [18]. Це пояснює також чому у хворих на ХОЗЛ частіше зустрічаєтья 
діастолічна дисфункція ніж систолічна. Систолічній дисфункції ПШ, як правило, передує діастолічна. Якщо діастолічна дисфункція ПШ регіструється, починаючи 32 ст. ХОЗЛ, то діастолічна дисфункція ЛШ спостерігається уже на 1 ст. захворювання. При ізольованому ХОЗЛ діастолічна дисфункція ПШ при ЕХОКГ візуалізується у 55-60\%, ЛШ - у 66-87\% [18]. Діастолічна дисфункція є основою виникнення $\mathrm{CH}$ зі збереженою фракцією викиду. Вона спричинює підвищення тиску $\mathrm{y}$ лівому передсерді та його пере розтягнення, що $\epsilon$ морфологічним субстратом виникнення аритмій (фібриляція передсердь, шлуночкові порушення ритму, у тому числі фатальні). У зв'язку із цими поглядами актуальними $\epsilon$ спостереження А.Л. Міхньова у роки війни: «Состояние миокарда является одним из наиболее существенных гемодинамических факторов... С патологическим процессом в миокарде обычно связаны случаи внезапной тихой смерти, наступающей ночью во сне, а также, когда человек сидит где-либо за столом, когда сердце сразу останавливается без предшествующих болевых приступов, без удушья».

3. Відповідно до сучасних уявлень ХОЗЛ вважається захворюванням із системними (екстрапульмональними) проявами. Причинами виникнення системних реакцій у хворих на ХОЗЛ є запальна активність клітин легеневої тканини на грунті хронічного системного запалення, активація нейтрофілів/лімфоцитів, збільшення рівня цитокінів і гострофазних протеїнів у плазмі хворих. Рівень системного запалення залежить від тяжкості захворювання. При ХОЗЛ клітини запалення накопичуються не лише в паренхімі легень та бронхів, а й у судинній стінці. Передбачається, що посилення локального запалення в бронхах, легеневій паренхімі і судинах веде до системної дії медіаторів i маркерів запального процесу, сприяє прогресуванню ХОЗЛ, атеросклерозу, кардіоваскулярних ефектів, ураженню інших органів [19, 20]. Важливо, що А.Л. Міхньов у розвитку та прогресуванні хронічного бронхіту та емфіземи легень теж придавав значення запальним процесам: «... в основе их развития лежат одни и те же воспалительные процессы, вызывающие атрофию активных элементов тканей бронхов и легких», і далі: «главная роль в развитии эмфиземы принадлежит конституциональным особенностям мезенхимальных элементов...». Нагадаємо, що «мезенхімальні елементи» у розумінні А.Л. Міхньова - складова частина сполучної ткани, якій на той час придавалось важливе значення у розвитку патологічних прпоцесів. А сполучна тканина в сучасних уявленнях плацдарм запальних та імунних реакцій.

Аліментарна дистрофія. Аліментарна дистрофія - одне чи не само древніх захворювань людства, що вражало його у великих масштабах у неврожайні роки, у часи різного народного лиха, війн та соціальних потрясінь.

Практично всі відомі великі війни супроводжувалися «набряковими епідеміями», що мали місце в арміях воюючих сторін - у роки наполеонівських війн, у російсько-турецьких війнах, у Першу світову війну.

Роки Другої світової війни теж не були виключенням, проте про аліментарну дистрофію писалося тільки, як правило, у закордонній медичній літературі. Що стосується радянської літератури, то аліментарна дистрофія згадувалася, в основному, з голодом у блокованому Ленінграді. Адже важко було замовчати факт загибелі майже одного мільйона людей від голоду, та хвороб, йому супутніх. Сьогодні вже відомо про значне поширення голоду серед цивільних людей, полонених та людей на примусових роботах. Проте страждали від голоду і хворіли на аліментарну дистрофію і бійці Червоної армії.

Знаючи про всевидяче око сталінської цензури на війні, можна тільки дивуватися, як взагалі могла появитися у книзі ця глава. Адже мова йтиме не про блокадний Ленінград, не про військовополонених, а про військовослужбовців Калінінського фронту, правда у книзі вони подаються як «лица вышедшие из бывших оккупированных областей». Думаємо, що мова йде про бійців, які вибиралися 3 німецького оточення. Тоді таких «контингентів» по всьому радянсько-німецькому фронті були мільйони. Це не перебільшення, стоїть тільки допитливому читачеві звернутись до сучасних матеріалів (не радянських і не російських) про цю війну. Голодували і бійці, що були у діючій армії з величезним генеральським, партійнополітичним i репресивним аппаратом, 3 потужною службою матеріально-технічного, зокрема продовольчого забезпечення.

Але відволіктемося від книги А.Л. Міхньова і звернемося до спогадів командувача Калінінським фронтом генерал-полковника I.I. Єременко. 29 квітня 1943 р. він прийняв фронт від командувача генерал армії М.А. Пуркаєва, що терпів безперервні поразки. Ситуація на фронті була катастрофічною, особливо погано було налагоджено забезпечення військ 
продовольством. Ось як описав ситуацію у своєму щоденнику A.I. Єременко: «случались большие перебои в питании, люди не доедали из-за плохой организации снабжения, за что и сняли Пуркаева. В первом квартале 1943 года было 76 случаев смерти от истощения. В связи с этим проходила конференция врачей. Некоторые медики, в том числе и начальник санупрфронта (Бурназян A.I. - автор), доказывали, что наш паек плохой - мало калорий, из-за этого солдаты болеют дистрофией и умирают. Эту вредную теорию мы разбили. Организовали нормальное снабжение, контроль за сохранностью продуктов, и дело пошло на лад [26]. Враховуючи, що летальність від аліментарної дистрофії була не такав же й велика - лікарі навчилися спасати хворих, адже «школа» голоду у 30-х роках була серйозною, то якщо померло 76 хворих, тоді можна приблизно уявити, скільки було всього хворих 3 дистрофією на Калінінському фронті.

По зрузумілій причині у книзі не вказується і кількість хворих, що спостерігалися автором. Для наукової роботи це не припустимо, але... - які то були часи.

Ось як описує А.Л. Міхньов хворих, що поступали до евакогоспіталю №3420, де він служив начальником терапевтичного відділення, потім провідним терапевтом:

«Первые случаи алиментарной дистрофии были отмечены нами в январе месяце 1942 года среди лиц, вышедших из бывших оккупированных областей. С февраля месяца 1942 г. по май 1943 г. через Н-ский эвакогоспиталь прошла ЗНАЧИТЕЛЬНАЯ (виділено автором) группа таких больных с алиментарной дистрофией. Судя по анамнестическим данным и клинической симптоматологии, все они долгое время находились в условиях количественного и качественно недостаточного питания, выполняя тяжелую физическую нагрузку, подвергаясь низкой внешней температуре, живя в лесах и сырых заболоченных местностях».

Серед обстежених 58\% мали набрякову форму і $42 \%$ - кахектичну. Клінічна картина у хворих на аліментарну дистрофію була надзвичайно різноманітною. Iз ранніх симптомів відзначалися: загальна слабкість, постійне відчуття втоми, сонливість, мерзлякуватість, полакіурія, поліурія, ніктурія, постійне відчуття голоду і відсутність відчуття насичення при достатньому харчуванні.

3 обєктивних ознак набрякової форми дистрофії на перший план виступали набряки на ногах, які потім швидко розповсюджувалися по всьому тілу. А.Л. Міхньов посилається на свого вчителя - М.Д. Стражеско, яким було показано, що у патогенезі набряків основне значення мало зменьшення загальної кількості сироваткових білків, основним чином альбумінів, що внаслідок падіння колоїдноосмотичного тиску призводило до затримки води в інтерстиціальному просторі. Певне значення мали місце підвищена проникність капілярних мембран і затримка хлориду натрію у тканинах.

При сухій формі дистрофії набряків, як правило, не спостерігалося, або вони були незначними на нижніх кінцівках. Звертало увагу на себе значне виснаження. Патогенез цієї форми дистрофії не мав чіткого пояснення, хоча А.Л. Міхньов відмічав у багатьох випадках зниження функції щитоподібної залози та функції адреналової системи. Можливо цей факт мав значення у розвитку сухої дистрофії.

3 обєктивних симптомів дистрофії відмічалися значні зміни зі сторони шкіри: сухість, втрата еластичності, лущення, петехіальні крововиливи, піодермія, пігментні пятна, зміна кольору (коричнево-бура). Обличчя маскоподібне, амімічне.

При сухій формі адинамія була виражена значно більше, ніж при набряковій. Більшу частину часу хворі спали, важко просипалися, щоб тільки поїсти. Сила мязів значно ослаблена, їх атрофія досягала крайніх ступенів. Суха форма дистрофії мала більш негативний, з точки зору прогнозу, перебіг, ніж набрякова.

Значні порушення спостерігалися з боку травного тракту. Особливо дошкуляли хворим проноси (у 65\%), вони не рідко були кровавими і тоді помилково діагностувалася дизентерія. Проноси спостерігалися уже на ранніх стадіях захворювання. Вони пояснювалися зниженням зовнішньосекреторної функції підшлункової залози та шлунку, гіповітамінозом та виділенням через слизову оболонку кишечника токсичних продуктів, що утворювалися в організмі внаслідок порушенного харчування та безпосередньої токсичної дії їх на шлунковокишковий тракт.

Зі сторонни серцево-судинної системи відмічалися: брадикардія у покої, артеріальна та венозна гіпотонія, тахікардія при незначних фізичних нагрузках.

Зі сторонни крові: гіпохромна анемія, анеозинофілія, лімфопенія, проскорена ШОЕ.

На фоні аліментарної дистрофії не рідко спостерігалося загострення старих хронічних захворювань та інфекцій, особливо це 
стосувалося туберкульозу легень і виразкової хвороби. При цьому туберкульозний процес не супроводжувався запальною реакцією, температура тіла залишалась нормальною або субфебрильною.

Що стосувалося лікування аліментарної дистрофії, то крім лікувального харчування, медикаментозної терапії (соляна кислота 3 пепсином, натуральний шлунковий сік, панкреатин, сульфадин, глюкоза) в евакогоспіталі вперше широко застосовувалося дробове переливання одногрупної крові 3 проміжками у 2-3 дні, а також призначався гематоген всередину, який отримували 3 гемолізованої крові. Фізичні методи лікування (світові ванни, загальний кварц та інші) теж давали гарні результати, особливо при болях у нижніх кінцівках внаслідок міалгій та невралгій, що були частими супутниками дистрофії.

\section{Актуальність} проблеми

для

сьогодення. Казалось би, що у наші часи аліментарна дистрофія увійшла до історії. Проте це не так. Аліментарна дистрофія, у тому числі і для армії, зберігає свою актуальність і в мирний час. Звичайно, що офіційна військова медицина не повідомляє широкому загалу про цю проблему.

Досить розповсюдженим явищем у радянській армії був так званий «дефіцит маси тіла» (ДМТ). Про ДМТ багато говорилося i писалося у закритих джерелах, інструктивнометодичних матеріалах, що «спускалися» 3 Москви, з вищих військових штабів, з медичної служби округів тощо. $\mathrm{y}$ цих документах надавалися рекомендації як виявляти військовослужбовців строкової служб из ДМТ, як їх лікувати, організовувати харчування. Солдати з ДМТ особливо часто зустрічалися у віддалених військових округах 3 різкоконтинентальним кліматом, у 40-й армії, що вела бойові дії в Афганістані [22].

Мені, як автору цих «Нарисів», у роки служби у Забайкальському військовому окрузі (1981-1991 pp.) на посадах начальника терапевтичних відділень великих госпіталів, провідного терапевта окружного військового госпіталю, головного терапевта округу, приходилося безпосередньо займатися цєю проблемою: організовувати активне виявляння військовослужбовців з ДМТ у підрозділах, їх обстеження та лікування. Осіб з ДМТ, особливо серед військовослужбовців перших місяців служби, було настільки багато, що у деяких військових частинах створювалися спеціальні «команди», для яких розроблялися відповідні лікувально-профілактичні заходи. У госпіталях діагноз ДМТ не виставлявся, такі військовослужбовці проходили під іншими діагнозами, благо здорових призовних контингентів у радянській армії було мало. Зустрічалися і вападки смерті від аліментарної дистрофії, яка наступала від інших захворювань, що розвивалися на ії фоні - гострих пневмоній, інфекційних захворювань, травм тощо.

Проблема ДМТ зберігається і в сучасній російській армії. У свій час (зима 1992-1993рр.) широкого розголосу отримала трагедія на острові Руський (Тихоокеанський флот), де виникли масові захворювання на аліментарну дистрофію, від якої, тільки офіційно визнано, померло четверо новобранців [23]. Детально трагедія описана у книзі Петра Фурси “Мечты и трюмы Российского флота» $(1995,2003)$.

На зборах керівного складу медичної служби РФ 30 травня 1994 р. начальник ГВМУ МО РФ генерал-полковник медичної служби І.М.Чиж відмічав, що «растет количество военнослужащих, имеющих дефицит массы тела... остается нерешенной проблема организации медицинского контроля за лицами с недостаточным питанием. В ряде видов ВC, округов и флотов ослаблен контроль за физическим развитием и статусом питания военнослужащих, что особенно наглядно проявилось на о. Русский (ТОФ)» [24].

Сьогодні у Росії 20-25 млн. людей з трудом забезпечують себе харчуванням, за офіційними даними у цій країні недоїдало (голодувало) 5$6 \%$ населення. Сюда не включалися бомжі, безпризорні та інваліди. 50-70\% населення харчується нижче медичних норм (недоотримує білків). Міністерство оборони Росії не змогло призвати в армію 50 тис. молодих людей по причині хронічного дефіциту маси тіла із-за недоїдання. Ще 20 тис. чоловік відправляють до армії з ДМТ, де їх відкормлюють до досягнення нормальної маси тіла. «Многие ребята только в части впервые в жизни ели вдосталь, а некоторые из них раньше даже не видели мяса» - розповів заступник командира однієї з частин Московського військового округу [25].

Співзвучна цим даним і заява заступника начальника Головного військово-медичного управління МО РФ генерал-майора медичної служби А.Нікітіна, який заявив, що кожний шостий бранець російської армії має ДМТ, що нерідко $\epsilon$ причиною низького спротиву організму до різних захворювань. «Если сказать простым человеческим языком, он недокормленный. 0 каком иммунитете можно говорить у человека, который не имеет 
достаточной мышечной, жировой массы» пояснив Нікітін [27].

У дисертації О.М.Русейкиної вказується на високу розповсюдженність патологічного дефіциту маси тіла - 18\% від загального числа військовослужбовців строкової служби російської армії. 3 обстежених 289 осіб 3 недостатністю харчування у $36 \%$ діагностовано дезадаптаційний ДМТ, у $32,5 \%$ конституційний дефіцит, у $31,5 \%$ - ДМТ аліментарного ґенезу [28].

Відомий радянський і російський фахівець з проблем недостатнього харчування професор, полковник медичної служби В.М.Луфт вважає, що серед осіб, які призиваються на військову службу у російській армії ДМТ може коливатися від 4 до 18\% у залежності від регіону призову, складаючи у середньому 10,5\% [29].

На початку розбудови української армії спостерігалася подібна ситуація і в нас. Аналізуючи особливості перебігу гострої пневмонії у 872 військовослужбовців строкової служби ми виявили, що у 56,4\% з них мав місце ДМТ від 5 до 20 кг. Була встановлена пряма залежність між вираженністю ДМТ і важкістю захворювання [30].

Начальник ГВМУ МО України генералмайор медичної служби В.Я. Білий в інтерв'ю журналу «Страна врачей» у травні 2001 р. повідомив: «В армию приходят люди, с которыми по состоянию их здоровья должны работать медики. Очень много ребят с дефицитом веса. Мы формируем целые команды, грубо говоря, «откормочные», чтобы за 2-3 месяца солдат довести до нормального соотношения рост/вес. Они очень долго адаптируются к условиям службы, многие впервые едят три раза в день! В общем, по статистике, у нас на каждую тысячу ребят полторы тысячи заболеваний, т.е. у каждого по полторы болезни» [31].

Таким чином, проблема недостатнього харчування, а відтак і можливість виникнення захворювань недостатнього харчування $\epsilon$ актуальною і в наш час, у тому числі і серед військовослужбовців.

Про спільність симптомів та диференційну діагностику міокардіодистрофій, Брайтової хвороби і аліментарної дистрофії. Ця тема була вибрана А.Л. Міхньовим у звязку з частими помилками, що допускали лікарі не тільки передових етапів евакуації, але і лікарі евакогоспіталів фронтової ланки та тилу.

Загальним симптомом у цих трьох захворювань виступали набряки. Розглядаючи міокардіодистрофії, А.Л. Міхньов мав на увазі важкі їх форми (декомпенсовані форми), що проявлялися серцевою недостатністю.

Розглядаючи міокардіодистрофії, варто внести деякі пояснення щодо розуміння цієї нозології у роки Другої світової війни. Звертає на себе увагу, що із всіх можливих причин серцевої недостатності автор зупинився саме на міокардіодистрофіях, а не на інших причинах (пороки серця, кардіосклероз тощо), а також те, що таких хворих було досить багато. Справа у тому, що нинішне розуміння цього захворювання і того, як його розуміли у роки війни, значно відрізняються.

Не було чіткого розуміння що таке міокардіодистрофія і серед лікарів у роки війни. Так, професор 0.0. Кедров, аналізуючи усі причини виникнення у роки війни серцевої недостатності, виявив (за даними звітів) міокардіодистрофію як причину розвитку серцевої недостатності у $39 \%$, ревматичні ураження серця - у 4,7\%, пороки серця - у $27,9 \%$, кардіосклероз - у 8,4\%, гіпертонічну хворобу - у $6,4 \%$, легеневе серце - у 12,4\%, інші захворювання серцево-судинної системи - у $1,2 \%$. Звідси видно, що у роки війни міокардіодистрофія була найбільш частою причиною серцевої недостатності. Чи насправді це було так? - питання інше.

3 однієї сторони, як відмічав сам 0.О. Кедров, помилковий діагноз «дистрофії міокарда» було поставлено у 5-6\% хворих, що пояснювалося недостатнім знайомством лікарів 3 класифікацією захворювань міокарда, прийнятою 12-м Всесоюзним з'їздом терапевтів у 1935 р. Запропоноване Г.Ф. Лангом визначення міокардиодистрофії мало на увазі функціональні зміни у міокарді без обов'язкового морфологічного субстрату і в її основі завжди мав бути який-небудь етіологічний момент - інфекційні захворювання, токсини, порушення обміну речовин, голодування, авітамінози, трофічні нервові порушення, перевтомлення. Відсутність у багатьох випадках можливості проведення ЕКГ - призводили до гіпердіагностики міокардіодистрофій.

3 другої сторони, умови воєнного часу самі по собі сприяли тому, що частота цього захворювання дійсно була вищою, ніж у довоєнний період. У роки Другої світової війни до лав влилися значні контингенти осіб різного віку, що у минулому перенесли ті чи інші захворювання (у тому числі інфекції, ревматизм), у зв'язку з чим у них мали місце певні зміни зі сторони серцево-судинної системи, що не заважали нести військову 
службу, або вони не виявлялися при призові. Значні фізичні і нервово-психічні навантаження (тривалі марші по пересіченій місцевості, переохолодження, неповне або повне голодування, нервово-психічна травматизація тощо), пов'язані з умовами бойової діяльності військ, пред'являли значні вимоги до вже патологічно зміненої серцево-судинної системи і зумовлювали розвиток у таких осіб (а їх була значна кількість) серцевої недостатності [32].

Розвиток набрякового синдрому при серцевій недостатності, головним чином правого серця, свідчив про серйозні гемодинамічні порушення, що проявлялися, крім набряків, цілою низкою інших симптомів, доступних фізичним методам дослідження.

До таких симптомів відносилися: розширення серця внаслідок його міогенної дилятації, прискорення серцевих скорочень, підвищення венозного тиску (набухання зовнішньої і внутрішньої яремних вен та їх пульсація), задишка. Задишка і відчуття сильного втомлення при фізичних навантаженнях - були першими проявами серцевої недостатності. Застій крові у печінці проявлявся ï збільшенням - один 3 ранніх та чутливих симптомів серцевої недостатності.

Таким чином, як видно з наведених вище сиптомів серцевої недостатності, діагностика при уважному обстеженні хворого не була важкою. Як показав досвід А.Л. Міхньова ігнорування саме ретельного клінічного обстеження хворих на практиці часто призводило до діагностичних помилок і вони попадали у розряд набрякової форми аліментарної дистрофії.

Що стосувалося аліментарної дистрофії, то діагностика зазвичай не визивала труднощів. Для неї характерними, визначальними симптомами були: брадикардія, гіпотонія, гіпотермія, уповільнене диханння.Набряки появлялися спочатку на лиці, або, частіше виникали одночасно на лиці та нижніх кінцівках, швидко розповсюджуючись по всьому тілу. Набряки при серцевій недостатності чітко слідували законам тяжіння, тобто вони появлялися на тих участках тіла, які нижче всього були розташовані по відношенню до серця, розповсюджуючись поступово все вище. Вони були досить стійкими. Набряки же при аліментарній дистрофії швидко проходили навіть від ліжкового режиму, відповідного харчування, навіть без застосування медикаментозних засобів.

Непросто було провести диференційну діагностику 3 нефритом. Поява у сечі альбумінурії, без інших симптомів захворювання, зовсім не означало наявність патології нирок. Посилаючись на досить ретельно опрацьований огляд літератури (зарубіжної та вітчизнянної) А.Л. Міхньов звертав увагу на те, що в умовах війни не можна не враховувати вплив низки екзогенних та ендогенних факторів (фізичне перевантаження, сильні емоції, ацідоз, переохолодження тощо), які можуть визивати альбумінурію, циліндрурію та мікрогематурію. Подібні зміни можуть супроводжувати i аліментарну дистрофію. Більше того, альбумінурія виявлялася і у здорових людей, у тому числі у спортсменів. У книзі А.Л. Міхньов детально зупинився на механізмах розвитку альбумінурії, вказуючи на те, що іiі поява не завжди $\epsilon$ наслідком анатомічного ураження нирок. Тому не слідує зловживати діагнозом запалення нирок, коли відсутні інші симптоми, характерні для хвороби Брайта. Обгрунтовувати діагноз нефриту тільки по незначним змінам у сечі, значить допускатися грубої помилки.

Враховуючи, що нефрит розвивається i перебігає на фоні гіперергічного стану організму, то він рідко зістрічався у хворих на аліментарну дистрофію. Як, до речі, і гострий ревматизм.

У заключенні до цієї глави автор зупинився на інших помилках, що допускалися при аліментарній дистрофії. Часто до цієі категорії хворих зараховували пацієнтів 3 хронічними захворюваннями шлунковокишкового тракту, органів дихання, особливо з туберкульозом легень, у яких виснаження залежало, основним чином, від основного захворювання i, по суті, принципово відрізнялося від аліментарної дистрофії.

Лікування малярії внутрішньовенним введенням хініну. У роки Другої світової війни малярія була досить розповсюдженим захворюванням. Загальноприйнятих схем лікування не існувало, не дивлячись на велику кількість протималярійних препаратів, які появилися в основному після 1940-го року (атебрин, мепакрин, памакин з групи акрихіну; сульфадіазин, плазмоцид, плазмохін, хінолінові препарати). До 1940 р. використовувався, в основному, хінін. 3 появою нових препаратів були запропоновані різні способи їх застосування: у середину, внутрішньомязово, внутрішньовенно. Хінін став застосовуватися рідше, а внутрішньовенне його введення рекомендувалося тільки при коматозних та гіпертоксичних формах малярії. 
Враховуючи, що нові протималярійні препарати визивали багато побічних ефектів, а також необхідність швидкого одужання i найскорішого повернення бійців до лав, А.Л. Міхньов запропонував лікувати усіх хворих на малярію внутрішньовенним введенням хініну. Таке лікування було проведене більше ніж у 300 хворих на «триденну» малярію. Застосовувався $2 \%$ розчин соляно-кислого хініну на фізіологічному розчині у кількості 25,0 мл на одно введення. Вливання проводилися щоденно на протязі 10-12 днів.

На відміну від авторів, що попереджували про велику кількість ускладнень від такої методики лікування, А.Л. Міхньов та його колеги не спостерігали особливих ускладнень, хоча виконали більше ніж 3000 вливань. 3 метою уникнення побічних ефектів препарат рекомендувалося вводити дуже повільно та не застосовувати великі його концентрації.

Лікування внутрішньовенним введенням хініну порівнювалося із застосуванням акрихіну та прийомом хініну всередину. При порівнянні результатів виявилося, що запропонований А.Л. Міхньовим метод призводив до більш швидкого одужання. Напади малярії обривалися уже на 2й день. Тривалість терапевтичного ефекту теж була значнішою. Особливо добре піддавалися такому лікуванню хворі 3 епімалярійними захворюваннями (малярійні набряки, бронхіти, нефрити, артрити тощо).

\section{Висновки}

1. Оскільки у надані медичної допомоги військовослужбовцям 3С України на Сході України активну участь приймають терапевти і лікарі терапевтичного профілю (більшість санітарних втрат на цій війні $€$ втрати саме терапевтичного профілю), фундаментальні погляди А. Міхньова на етіопатогенез та терапію бойовоїтерапевтичної патології $\epsilon$ важливими і не втрачають своєї актуальності.

2. Звичайно i, це вже чітко встановлений факт - низка захворювань внутрішніх органів мають певні особливості перебігу, які залежать від багатьох факторів (від театру воєнних дій, їх інтенсивності, застосування сучасного озброєння і бойової техніки, умов служби та побуту військовослужбовців тощо).

\section{Література}

1. Михнев А.Л. Очерки по военно-полевой терапии. - К., 1946. - 70 с

2. Бадюк М.І., Микита 0.О., Ковида Д.В. та ін. Стан захворюваності, госпіталізації та звільнень військовослужбовців сухопутних військ Збройних сил України//Військова медицина України - 2014 № 1 - c. 12-16/
Це дослідження А.Л.Міхньов проводив разом 3 лікарями Ф.І. Зенченко та Д.І. Сипитенером. Його результати надруковані у збірнику «Военная медицина в Великую Отечественную войну» (1946 рік, випуск 3).

Актуальність для сьогодення. Малярія і на сьогодні $\epsilon$ досить розповсюдженим захворюванням у багатьох країнах світу (за даними В003 вона загрожує 50\% населення світу), а з розвитком туризму - все частіше зустрічається в Україні, у тому числі у миротворців, що приймали участь в операціях OОН та НАТО [33].

Hе дивлячись на велику кількість протималярійних препаратів, найпоширенішим медикаментом для лікування малярії, як i раніше, $\epsilon$ хінін. Він особливо показаний при лікуванні церебральних форм тропічної малярії та ії̈ ускладнень, так як він єдиний препарат, що проникає через гематоенцефалічний барєр.

На жаль, на сьогодні хінін не входить до «Державного реєстру лікарських засобів в Україні». Ми у своїй практиці також зустрічалися 3 випадками лікування важких форм малярії, коли необхідно було застосувати внутрішньовенне введення хініну. Препарата в Україні не виявилося, прийшлося його отримати завдяки допомозі посольства країни, де хінін був зареєстрований. Тож невелика кількість хініну, фактично для надання невідкладної допомоги, у державі має бути.

3. Міхньов А.Л. звертає увагу на те, що умови служби і побуту бійців та командирів діючої армії у роки Другої світової війни «знижують загальну опірність організму і послаблюють його сили в боротьбі з інфекцією. Ця обставина істотно позначається і на характері перебігу патологічного процесу, змінюючи клінічну картину цілого ряду захворювань, роблячи іiї різноманітною, даючи нові якісні прояви при взаємодії хвороботворних агентів 3 макроорганизмом». Такі особливості $\epsilon$ і тепер, а ï вивчення та вплив на здоров'я військовослужбовців, та на перебіг захворювань - $є$ одним із завдань військово-медичної служби. Прикладом для такого вивчення і $\epsilon$ книга А.Л. Міхньова «Очерки по военно-полевой терапии».

3. Кучер B.I. Захворюваність військовослужбовців ЗС України на хвороби органів дихання//Військова медицина України - 2015 - № 2 - с. $48-52$

4. Савицький В.Л., Трихліб В.І., Осьодло Г.В. та ін. Інфекційні захворювання органів дихання серед військовослужбовців під час проведення 
АТО//Військова медицина України - 2015 - № 1 - с. 45-53/

5. Юдина Л.В. Современные стратегии лечения острого бронхита бактериальной этиологии //Здоров’я України. - 2014. - № 22. - с. 3

6. Чучалин А.Г., Абросимов В.Н. Кашель. 4-е издание. - М., 2016. - с. 61

7. Хіміон Л.В., Ященко О.Б., Данилюк С.В., Ситюк T.0. Симптоматичне лікування кашлю у дорослих//Здоров'я України. - 2016. - № 1. - с. 3

8. Зулкарнеев Р.Х., Загидуллин Ш.З., Власова Н.А. Сульфидинотерапия пневмонии в годы Великой Отечественной войны 1941-1945

гг.//Пульмонология - 2017 - № 3 - с. 427-430

9. Михньов А.Л. О некоторых особенностях течения крупозной пневмонии и о лечении её внутривенным введением сульфидина// Врачебное дело. - 1945. - № 7-8. - с. 310-314

10. Березняков В.И. Опрос врачей практического здравоохранения о ступенчатой терапии. У кн.: Сучасні аспекти військової медицини. Збірник наукових праць. Випуск 22. Частина 2. - К., 2015. - с. 3-8

11. Іванько О.М., Луцька А.В., Івачевська Н.С. Оцінка знань щодо використання антибіотиків при підготовці військових лікарів//Військова медицина України. - 2020. - № 4. - с. 106-109

12.Болезни органов дыхания. Под ред. Н.Р. Палеева. - М., 2000. - с. 231;

13. Ходош Э.М., Крутько В.С. Инфекционные деструкции легких: эволюция взглядов//Клінічна імунологія. Алергологія. Інфектологія. - 2017. - № 78. - с. $5-17$

14. Мостовий Ю.М., Слепченко Н.С., Дмитрієв К.Д., Сидоров А.А. Хронічне обструктивне захворювання легень та серце: здобутки та питання сьогодення//Український

журнал. - «018. - № 4. - с. 56-61 пульмонологічний

15. Бережницкий М.Н., Киселева А.Ф., Бигарь В.П. Хроническое легочное сердце. - К., 1991. - 152 с.

16. Гаврисюк В.К. Хроническое легочное сердце в свете положений международных руководств NICECOPD и GOLD // Український пульмонологічний журнал. - 2014. - № 2. - с. 17-19

17. Фещенко Ю.І. Актуальні проблеми діагностики і терапії ХОЗЛ із супутньою патологією//Український пульмонологічний журнал. - 2009. - № 2. - с. 6-10

18. Вишнивецький I.I., Холопов Л.С., БаташоваГалинська В.О. Клінічна характеристика дихальної та серцево-судинної систем при поєднанні хронічного обструктивного захворювання легень i серцевої недостатності//Запорожский медицинский журнал. - 2017. - № 3. - c. 250-255

\section{References}

1. Mykhnev, A.L. (1946). Essays on military field therapy. K., 70 p [in Russian].

2. Badyuk, M.I., Mykyta, O.O., Kovyda, D.V. (2014). The state of morbidity, hospitalization and dismissal of servicemen of the land forces of the Armed Forces of Ukraine. Military Medicine of Ukraine. 1; 12-16. [in Ukrainian]

3. Kucher, V.I. (2015). Morbidity of servicemen of the Armed Forces of Ukraine for respiratory diseases. Military Medicine of Ukraine. 2; 48-52. [in Ukrainian]
19. Акрамова Э.Г. Клиническое значение исследования сердца у больных ХОБЛ//Российский кардиологический журнал. - 2012. - № 1. - с. 41-47

20. Островський М.М., Герич П.Р. До питання поліморбідності та комор бідності у хворих на ХОЗЛ//Український пульмонологічний журнал. 2011. - № 4. - c. 19-24

21. Мостовой Ю.М., Слепченко Н.С., Дмитрієв К.Д., Сидоров А.А. Хронічне обструктивне захворювання легень та серце: здобутки та питання сьогодення // Український пульмонологічний журнал. - 2018. - № 4. - с. 56-61

22. Ивашкин В.Т., Луфт В.М., Резунов А.А., Голуб В.И. причины и механизмы развития синдрома дефицита массы тела у военнослужащих в условиях жаркого климата и горнопустынной местности//Военно-медицинский журнал - 1991 - № 7 - с. $21-25$.

23. Електронний ресурс. Режим доступу: Russianbazaar.com/ru/content/10202.html

24. Чиж И.М. Задачи совершенствования организации медицинского обеспечения армии и флота//ВМЖ. - 1994. - № 8. - c. 6

25.Есть ли голодне в России/Новое время. Електронний ресурс. Режим доступу: https://nv.ua/.../est-li-golodnye-v-rossii-...

26. Електронний ресурс: nvo.nq.ru/history/2000-0428/6_marshall_trne.html

27. Мужчины-дистрофики отдают свой долг Родине. Електронний ресурс. Режим доступу: maxpark.com/community/33/...691548.

28. Русейкина О.М. Комплексная оценка трофологического статуса и реабилитация военнослужащих срочной службі с дезадаптационной недостаточностью питания. АДК, 2004

29. Луфт В.М. Причины, распространенность и клинические аспекты недостаточности питания//ВМЖ. - 1994. - № 4. - с.59-63

30. Асаулюк И.К., Стефанюк Н.Ф., Бойчак М.П. Влияние дефицита массы тела на возникновение и течение острых пневмоний у военнослужащих срочной службы. В кн.: Современные проблемы неотложной терапии в клинике внутренних болезней. Тезисы докладов научно-практической конференции. - К., 1992. - с. 68-70

31. Медведь В. Диалоги о медицине и жизни. Киев, 2007. - с. 32

32. Молчанов Н.C. Военно-полевая терапія (краткий курс). - М., 1953. - с. 94-95

33. Трихліб B.I. Аналіз повторних захворювань та рецидиви малярії серед миротворчих контингентів//Військова медицина України. - 2011. - № 3-4. - c. 107-112

4. Savytskyy, V.L., Trykhlib, V.I., Osodlo, H.V. (2015). Infectious diseases of the respiratory system among servicemen during the anti-terrorist operation. Military Medicine of Ukraine, 1 ; 45-53. [in Ukrainian]

5. Yudyna, L.V. (2014). Modern strategies for the treatment of acute bronchitis of bacterial etiology. Health of Ukraine. 22; 3. [in Ukrainian]

6. Chuchalyn A.H., Abrosymov V.N. (2016). Cough. 4th edition. M., 61. [in Russian]. 
7. Khimion, L.V., Yashchenko, O.B., Danylyuk, S.V., Sytyuk, T.0. (2016) Symptomatic treatment of cough in adults. Health of Ukraine. 1; 3. [in Ukrainian]

8. Zulkarneev, R.KH., Zahydullyn, SH.Z., Vlasova, N.A. (2017). Sulphidinotherapy of pneumonia during the Great Patriotic War of 1941-1945. Pulmonology. 3; 427430. [in Russian].

9. Mykhnov, A.L. (1945). On some features of the course of lobar pneumonia and its treatment with intravenous sulfidine. Vrachebnoe delo. 7-8; 310-314. [in Russian].

10. Bereznyakov, V.Y. (2015). Survey of general practitioners on step therapy]. In the book: Modern aspects of military medicine. Collection of scientific works. Issue 22. Part 2. K., 3-8. [in Ukrainian]

11. Ivanko, O.M., Lutska, A.V., Ivachevska, N.S. (2020). Assessment of knowledge on the use of antibiotics in the training of military doctors. Military Medicine of Ukraine. 4; 106-109. [in Ukrainian]

12. Respiratory diseases. (2000) Ed. N.R. Paleeva. M, 231. [in Russian].

13. Khodosh, E.M., Krutko, V.S. (2017) Infectious destruction of the lungs: the evolution of views. Clinical Immunology. Allergology. Infectology. 7-8; 5-17.

14. Mostovyy, Yu.M., Slepchenko, N.S., Dmytriyev, K.D., Sydorov, A.A. (2018). Chronic obstructive pulmonary disease and heart disease: achievements and issues of the present. Ukrainian Journal of Pulmonology. 4;. 56-61. [in Ukrainian]

15. Berezhnytskyy, M.N., Kyseleva, A.F., Byhar, V.P. (1991). Chronic pulmonary heart. K., 152.

16. Havrysyuk V.K. (2014) Chronic pulmonary heart in the light of the provisions of the international guidelines NICE-COPD and GOLD. Ukrainian Journal of Pulmonology. 2; 17-19. [in Ukrainian]

17. Feshchenko, YU.I. (2009). Actual problems of diagnosis and therapy of COPD with concomitant pathology. Ukrainian Journal of Pulmonology. 2; 6-10 [in Ukrainian]

18. Vyshnyvetskyy, I.I., Kholopov, L.S., BatashovaHalynska, V.O. (2017) Clinical characteristics of the respiratory and cardiovascular systems in the combination of chronic obstructive pulmonary disease and heart failure. Zaporozhye Medical Journal. 3;. 250255. [in Ukrainian]

19. Akramova, E.H. (2012). Clinical significance of the study of the heart in patients with COPD. Russian Journal of Cardiology. 1;. 41-47. [in Ukrainian]
20. Ostrovskyy, M.M., Herych, P.R. (2011). On the issue of polymorbidity and poverty barriers in patients with COPD. Ukrainian Journal of Pulmonology.4; 19-24. [in Ukrainian]

21. Mostovoy, Yu.M., Slepchenko, N.S., Dmytriyev, K.D., Sydorov, A.A. (2018). Chronic obstructive pulmonary disease and heart disease: achievements and issues of the present. Ukrainian Journal of Pulmonology. 4; 56-61. [in Ukrainian]

22. Yvashkyn V.T., Luft V.M., Rezunov A.A., Holub V.Y. (1991). Causes and mechanisms of development of the syndrome of body weight deficit in servicemen in hot climates and mountainous deserts. Military Medical Journal. 7; 21-25. [in Russian]

23. Elektronnyy resurs. Rezhym dostupu: http://russian-bazaar.com/ru/content/10202.htm [in Russian]

24. Chyzh, Y.M. (1994). Tasks of improving the organization of medical support of the army and navy Military Medical Journal. 8;. 6.

25. Is there a famine in Russia / New Time. Electronic resource. Access mode: https://nv.ua/ukr/opinion/estli-golodnye-v-rossii-63671.html

26. Electronic resource: nvo.nq.ru/history/2000-0428/6_marshall_trne.html

27. Dystrophic men pay their debt to the Motherland. Electronic resource. Access mode: https://maxpark.com/community/33/content/691548.

28. Ruseykyna, O.M. (2004) Comprehensive assessment of trophological status and rehabilitation of conscripts with maladaptive malnutrition. ADK

29. Luft, V.M. (1994). Causes, prevalence and clinical aspects of malnutrition. Military Medical Journal. 4; .5963.

30. Asaulyuk, Y.K., Stefanyuk, N.F., Boychak, M.P. (1992). Influence of body weight deficit on the occurrence and course of acute pneumonia in conscripts. In: Modern problems of emergency therapy in the clinic of internal medicine. Abstracts of reports of the scientificpractical conference. K., 68-70.

31. Medved, V. (2007). Dialogues about medicine and life. Kiev, 32.

32. Molchanov, N.S. (1953). Military field therapy (short course). M. 94-95.

33. Trykhlib, V.I. (2011). Analysis of recurrent diseases and relapses of malaria among peacekeeping contingents. Military Medicine of Ukraine. 3-4; 107-112. [in Russian]

\section{КНИГА АНАТОЛИЯ МИХНЕВА «ОЧЕРКИ ПО ВОЕННО-ПОЛЕВОЙ ТЕРАПИИ» И СОВРЕМЕННОСТЬ}

\section{М.П. Бойчак}

\section{Украинская военно-медицинская академия (2. Киев)}

Цель. Рассмотреть отдельные главы книги Анатолия Михнево «Очерки по военно-полевой терапии» u, по возможности, предоставить свое видение актуальности некоторых проблем, поднимал автор «Очерков», с точки зрения настоящего

Материалы и методы. В исследовании использованы исторический и библиосемантичний методы для полного раскрытия актуальности некоторых проблем, поднимал А.Л. Михнев в книге «Очерки по военнополевой терапии» с точки зрения современности.

Результаты исследования. Фундаментальные взгляды А. Михнево на этиопатогенез и терапию острых бронхитов военного времени, некоторые особенности течения крупозной пневмонии и ее лечения внутривенным введением сульфидина, патогенез и лечение легочных нагноительных процессов, патогенез и терапию кардиопульмональной недостаточности, алиментарной дистрофией, общность симптомов и 
дифференциальную диагностику миокардиодистрофий, Брайтова болезнь и алиментарной дистрофией, а также лечение малярии введением хинина залишиаються актуальными и в настоящее время.

Выводы. Поскольку в предоставлении медицинской помощи военнослужащим ВС Украины на Востоке Украины активное участие принимают терапевты и врачи терапевтического профиля (большинство санитарных потерь на этой войне есть потери именно терапевтического профиля), фундаментальные взгляды А. Михнево на этиопатогенез и терапию бойовоитерапевтичнои патологии являются важными и не теряют своей актуальность. Конечно и это уже четко установленный факт - ряд заболеваний внутренних органов имеют определенные особенности течения, которые зависят от многих факторов (от театра военных действий, их интенсивности, применение современного вооружения и боевой техники, условий службы и быта военнослужащих и т.д.). Михнев А.Л. обращает внимание на то, что условия службы и быта бойцов и командиров действующей армии в годы Второй мировой войны «снижают общую сопротивляемость организма и ослабляют его силы в борьбе с инфекцией. Это обстоятельство существенно сказывается и на характере течения патологического процесса, изменяя клиническую картину целого ряда заболеваний, делая ее разнообразной, давая новые качественные проявления при взаимодействии болезнетворных агентов по макроорганизмом ». Такие особенности есть и сейчас, а их изучение и влияние на здоровье военнослужащих, $и$ на течение заболеваний - является одной из задач военно-медиџинской службы. Примером для такого изучения и есть книга А.Л. Михнево «Очерки по военно-полевой терапии».

Ключевые слова: военно-полевая терапия, этиопатогенез и терапия, кардиопульмональная недостаточность, алиментарная дистрофия.

\section{ANATOLIY MIKHNOV'S BOOK "ESSAYS ON MILITARY FIELD THERAPY" AND THE PRESENT TIME}

\section{M.P. Boychak}

\section{Ukrainian military medical Academy, Kyiv}

The purpose: To consider separate chapters of Anatoly Mikhnev's book "Essays on military field therapy" and, if possible, to give the vision of urgency of some problems raised by the author of "Essays", from the up-to-date point of view.

Materials and methods. The study used historical and bibliosemantic methods to fully disclose the relevance of some issues raised by AL Mikhnev in the book "Essays on military field therapy" in terms of today.

Results. A. Mikhnev's fundamental views on the etiopathogenesis and therapy of acute wartime bronchitis, some features of croupous pneumonia and its treatment with intravenous sulfidine, pathogenesis and treatment of pulmonary purulent processes, pathogenesis and therapy of cardiopulmonary insufficiency and cardiopulmonary disease and nutritional dystrophy, as well as treatment of malaria with intravenous quinine remain relevant today.

Conclusions. Since therapists and physicians of therapeutic profile take an active part in the provision of medical care to servicemen of the Armed Forces of Ukraine in eastern Ukraine (most sanitary losses in this war are losses of therapeutic profile), Mikhnev's fundamental views on etiopathogenesis and therapy of combat therapeutic pathology are important and relevance. Of course, this is a well-established fact - a number of internal diseases have certain features that depend on many factors (from the theater of operations, their intensity, the use of modern weapons and military equipment, conditions of service and life of servicemen, etc.). Mikhnev AL draws attention to the fact that the living and working conditions of soldiers and commanders of the active army during the Second World War "reduce the body's overall resistance and weaken its strength in the fight against infection. This circumstance significantly affects the nature of the pathological process, changing the clinical picture of a number of diseases, making it diverse, giving new qualitative manifestations in the interaction of pathogens with the macroorganism. Such features are still present, and their study and impact on the health of servicemen, and on the course of diseases - is one of the tasks of the military medical service. An example of such a study is the book by A.L. Mikhnev "Essays on military field therapy." dystrophy.

Key words: military field therapy, etiopathogenesis and therapy, cardiopulmonary insufficiency, alimentary

\section{Відомості про авторів:}

Бойчак М.П., генерал-майор медичної служби у відставці, доктор медичних наук, професор кафедри військової терапії Української військово-медичної академії, м. Київ, Україна.

Сведения об авторах:

Бойчак М.П., генерал-майор медицинской службы в отставке, доктор медицинских наук, професор кафедры военной терапии Украинской военно-медицинской академии, г. Киев, Украина.

Information about author:

Boychak M.P., Major-general of MS, retired, DM DSc, Proff., professor of military therapy department at Ukrainian Military-Medical Academy, https://orcid.org/0000-0002-8289-6239

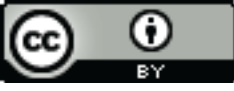

Адреса для листування: вул. Московська, 45/1, буд. 33, м. Київ 01015 